\title{
ANALISA DESAIN FLY OVER DAN SLAB ON PILE PADA PERENCANAAN JALAN LINGKAR BARAT KOTA SURABAYA
}

\author{
Ilanka Cahya Dewi ${ }^{(1)}$, Pujo Priyono ${ }^{(2)}$ \\ Program Studi Teknik Sipil Fakultas Teknik Universitas Muhammadiyah Jember ${ }^{1,2,3}$ \\ Jl. Karimata 49, Jember 68121, Indonesia \\ email : ilankadewi@unmuhjember.ac.id
}

\begin{abstract}
The increasing of traffic intensity need to be accommodated by a sufficient infrastructure, both roads and bridges. So the traffic flow fluency can be guaranteed. Surabaya's West Outer Ring Road is one of the sections with heavy traffic flow, while the land condition consists of swampy areas. For this purpose, make a road design with a fly over and slab on pile system that is efficient and fulfill the safety factor for its use. The methodology in this analysis are: (1) Review of the existing conditions, (2) 3 dimension structural analysis, both the bearing capacity of the foundation and the structure of fly over, full slab and slab on the pile, (3) Evaluation of the section capacity of the structure and foundation with the SAP 2000 V.14.2.5 software. The anlysis's result obtained by the fly over design for pier head beam uses $D 32$ for the main reinforcement, D25 for the shear, Type B elastomer. While the pier uses D32 for the longitudinal reinforcement, D16 for shear. The piles uses D600 with D22 for main and D13 for shear reinforcement, while pile cap uses D32 for the main reinforcement, D25 for shringkage and shear reinforcement. The design of full slab uses D13 for the main reinforcement during lifting condition and ultimate loads. For ultimate conditions uses D13 for x-direction and D22 for y-direction reinforcement. The type B elastomer is used for slab on pile. The type $C$ of pier is used with $D 600$ reinforcement, with D22 for the main and D13 for shear reinforcement. Pile head reinforcement uses D32 and D22 while the shear reinforcement is D19 and D16. The fly over slab design uses D19 for main reinforcement. The section capacity investigation of the fly over and slab precast structures on shear control, fracture, the lifting stress and deflection shows that the sections are fulfill the safety requirement.
\end{abstract}

Keywords: design, fly over, full slab, slab on pile

\begin{abstract}
Abstrak
Intensitas lalu lintas yang terus meningkat perlu diakomodir dengan penambahan infrastruktur, baik jalan ataupun jembatan. Sehingga kelancaran arus lalu lintas terjamin. Jalan lingkar Luar Barat Surabaya merupakan salah satu ruas jalan dengan arus lalu lintas yang cukup padat, sedangkan kondisi tanahnya mayoritas merupakan daerah rawa. Sehingga tujuan dari Analisa ini adalah untuk merencanakan jalan dengan sistem struktur fly over dan slab on pile yang ekonomis dan memenuhi segi keamanan serta rencana penggunaannya. Metodologi dalam Analisa ini adalah: (1) Peninjauan kondisi eksisting, (2) Analisa struktur 3 dimensi, baik daya dukung pondasi maupun struktur fly over, full slab dan slab on pile, (3) Evaluasi kapasitas penampang struktur dan pondasi dengan program bantu SAP 2000 V.14.2.5. Dari hasil perhitungan diperoleh desain fly over untuk balok menggunakan tulangan utama D32, tulangan geser D25, elastomer tipe B, sedangkan kolom pier menggunakan tulangan longitudinal D32, tulangan geser D16. Untuk tiang pancang menggunakan D600 dengan tulangan utama D22 dan tulangan geser D13, sedangkan pile cap menggunakan tulangan utama D32, tulangan susut D25, dan tulangan geser D25. Dengan jumlah dan jarak masingmasing sesuai hasil perhitungan. Untuk desain full slab, penulangan saat kondisi pengangkatan dan beban ultimit menggunakan tulangan utama D13, Penulangan pada kondisi ultimit menggunakan D13 untuk arah-x dan D22 untuk arah-y. Pada slab on pile, digunakan elastomer tipe B. Tiang pancang tipe C (D 600), tulangan utama D22, dan tulangan geser D13. Penulangan pile head menggunakan D32 dan D22 sedangkan tulangan geser D19 dan D16. Desain pelat lantai fly over menggunakan tulangan utama D19. Hasil evaluasi kapasitas penampang menunjukkan keamanan terpenuhi. Dan untuk struktur pracetak, dilakukan kontrol terhadap geser, retak, tegangan akibat pengangkatan, serta lendutan yang menunjukkan bahwa penampang aman.
\end{abstract}

Kata kunci: desain, fly over, full slab, slab on pile 


\section{Pendahuluan}

Surabaya merupakan salah satu kota metropolitan dan merupakan ibu kota propinsi Jawa Timur yang memiliki luas sekitar 326,81 $\mathrm{km}^{2}$ dengan jumlah penduduk lebih dari 3 juta jiwa. Dengan besarnya jumlah penduduk ini, maka mobilitas di kota Surabaya pun juga tinggi. Hal ini menuntut prasarana jalan yang memadai untuk para penggunanya.

Jalan Lingkar Luar Barat (JLLB) Surabaya merupakan salah satu ruas jalan di Surabaya yang memiliki intensitas lalu lintas cukup tinggi. Sehingga perlu dibangun infrastruktur jalan dan jembatan untuk memperlancar arus lalu lintas tersebut. Kondisi JLLB mayoritas merupakan daerah rawa, sehingga perlu dibangun sistem fly over dan slab on pile untuk melintasi daerah tersebut.

Sehingga penelitian ini bertujuan untuk melakukan Analisa terhadap jalan secara keseluruhan di daerah Surabaya Barat meliputi desain fly over dan desain slab on pile pada beberapa stasiun (STA.) tertentu

\section{Metodologi:}

1. Mempelajari data perencanaan dan data eksisting, baik data geometri, data tanah, rencana pondasi, dan penulangan yang terpasang

2. Melakukan Analisa struktur degan pemodelan 3 dimensi berdasarkan data geometri, untuk mengetahui distribusi gaya dalam maksimum yang bekerja pada pilar jembatan.

3. Melakukan evaluasi kapasitas penampang dan kapasitas pondasi terhadap gaya dalam yang terjadi

\section{Kriteria desain}

Jalan Lingkar Luar Barat Surabaya memiliki beberapa fly over dan slab on pile yang didesain untuk dapat ditopang oleh pondasi tiang pancang berjenis spun pile berdiameter $600 \mathrm{~mm}$. Pilar - pilar ini akan menopang jalur jalan yang berupa struktur PCI Girder. PCI Girder yang didesain disesuaikan dengan produk keluaran pabrik beton pracetak, sehingga girder hanya berlaku sebagai pendistribusi beban lalu lintas saat pemodelan struktur.
Perencanaan struktur jembatan yang ekonomis dan memenuhi segi keamanan serta rencana penggunaannya, merupakan suatu hal yang penting. Dalam hal ini, metode perencanaan struktur yang digunakan yaitu dengan metode perencanaan ultimit dengan pemilihan faktor beban ultimit sesuai SNI 031725-2016 tentang Tatacara Perencanaan Pembebanan Untuk Jembatan, dan SNI-032833-2013 tentang Tatacara Perencanaan Ketahanan Gempa untuk Jembatan. Metode selanjutnya menggunakan metode perencanaan tegangan ijin dengan beban kerja. Perencanaan ini menggunakan software SAP 2000 V.14.2.5
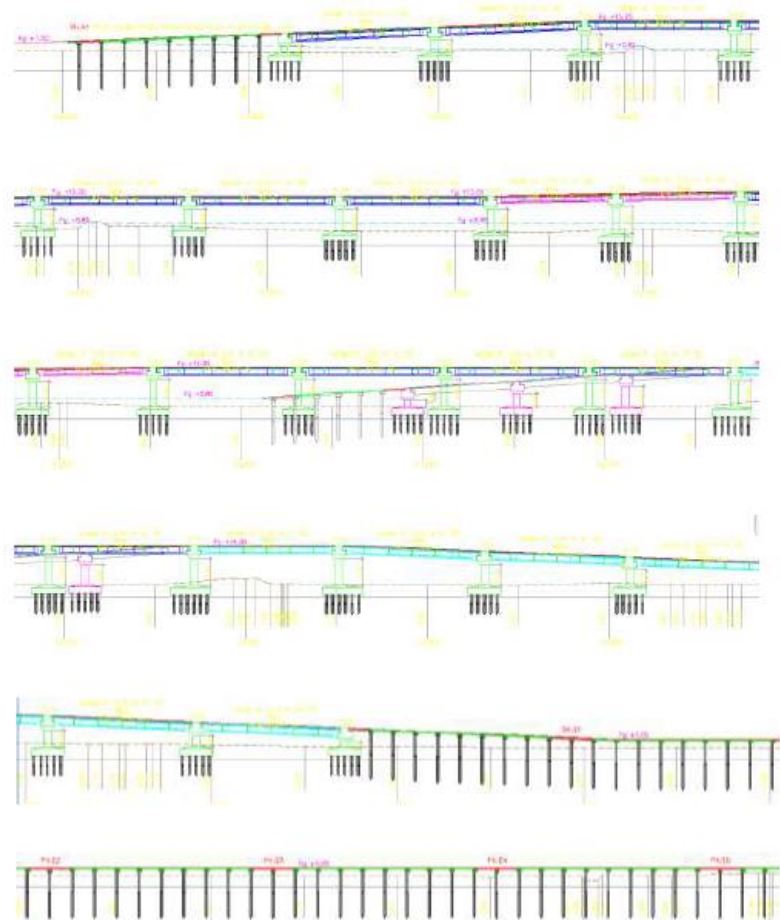

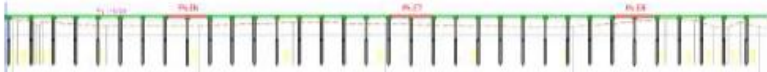

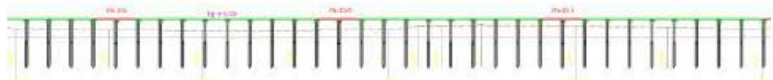

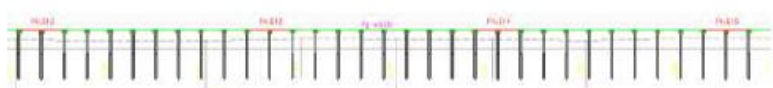

Gambar 1. Potongan Memanjang Rencana Pilar \& Slab on Pile 

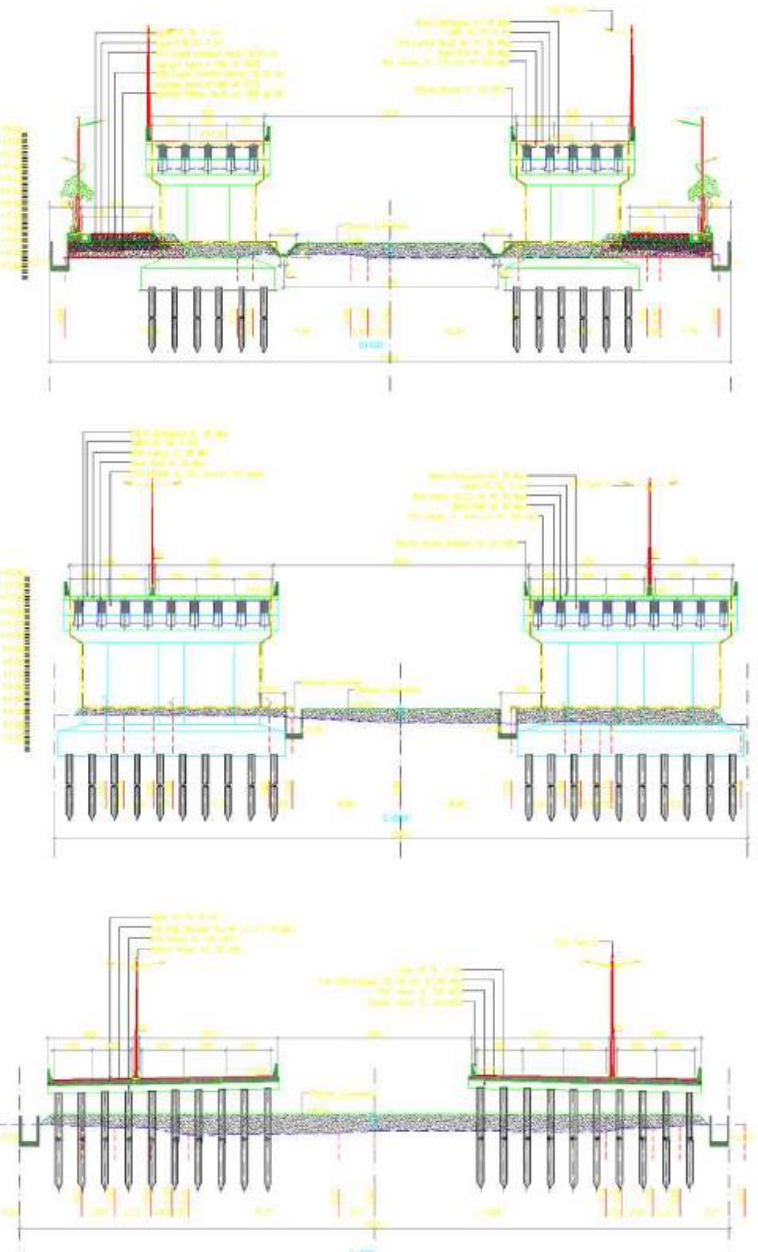

Gambar 2. Potongan Melintang Tipikal Rencana Pilar \& Slab on Pile

\section{Spesifikasi Material}

Material yang digunakan pada analisa struktur ini adalah:

a. Elemen struktur beton

Mutu beton $=\mathrm{K}-400 / \mathrm{f}$ "c $35 \mathrm{MPa}$

b. Tiang pancang

Diameter spun pile $=600 \mathrm{~mm}$

Ujung bawah $=$ kelas $\mathrm{A}$

Ujung atas $\quad=$ kelas $\mathrm{C}$

c. Tulangan baja ulir

Tegangan leleh, fy $=400 \mathrm{MPa}$

\section{Data pembebanan}

Data perencanaan pembebanan mengacu pada SNI 1725 - 2016 dan RSNI 2833201X, yaitu:

a. Beban mati akibat berat sendiri, $\mathrm{M}_{\mathrm{S}}$

- Beton bertulang $=2,500 \mathrm{~kg} / \mathrm{m}^{3}$

- Baja

$$
=7,850 \mathrm{~kg} / \mathrm{m}^{3}
$$

b. Beban Mati Tambahan, $\mathrm{M}_{\mathrm{A}}$
- Aspal $=2,200 \mathrm{~kg} / \mathrm{m}^{3}$

- Pelat beton $=2,500 \mathrm{~kg} / \mathrm{m}^{3}$

- Barrier \& Parapet $=2,400 \mathrm{~kg} / \mathrm{m}^{3}$

- Beban hujan $=1,000 \mathrm{~kg} / \mathrm{m}^{3}$

- Pipa Baja $\mathrm{MEP}=7,850 \mathrm{~kg} / \mathrm{m}^{3}$

c. Beban Hidup Lajur, TD

- Beban Garis Terpusat, BGT= 49 $\mathrm{kN} / \mathrm{m}$

- Beban Hidup Terbagi Rata, BTR untuk panjang jembatan $\leq 30 \mathrm{~m}$, $\mathrm{BTR}=9 \mathrm{kPa}$ untuk panjang jembatan $>30 \mathrm{~m}$, $\mathrm{BTR}=9(0.5+15 / \mathrm{L}) \mathrm{kPa}$.

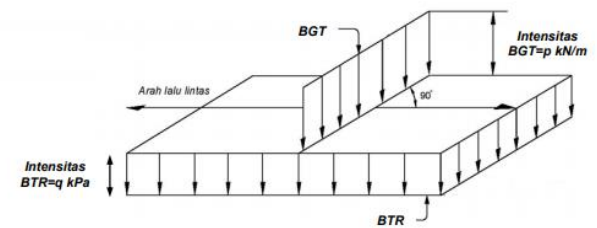

Gambar 3. Beban Lanjur D, Konfigurasi BGT dan BTR

(SNI 1725 Tahun 2016)

d. Beban Hidup Truk, TT

Menggunakan kendaraan truk semi trailer sesuai SNI 1725-2016
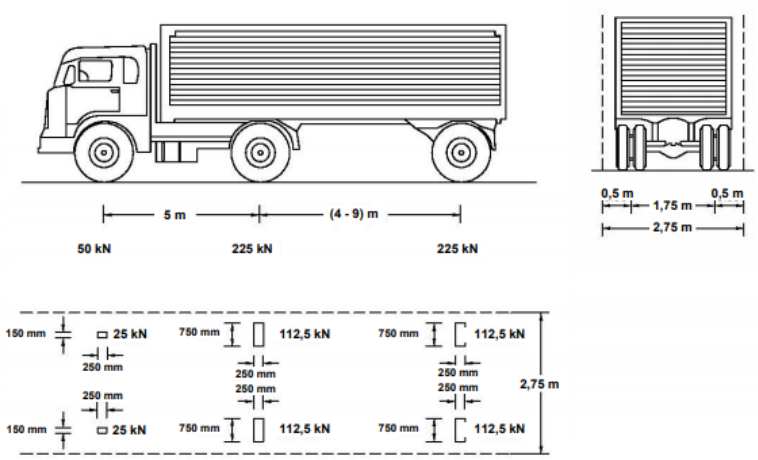

Gambar 4. Beban Truk 500 kN

(SNI 1725 Tahun 2016)

e. Beban Hidup Rem, TB

- Diambil sebesar $25 \%$ dari berat gandar truk atau

- 5\% dari berta truk rencana ditambah BTR

f. Beban Angin, W

Dalam desain struktur fly over dan slab on pile ini secara keseluruhan menggunakan struktur beton yang massif, sehingga beban angin berpengaruh kecil terhadap struktur, namun beban angin tetap diperhitungkan sebagai angin transfer 
ke lantai jembatan dan angin yang mengenai permukaan pilar

g. Beban Arus dan Hanyutan, $E_{F}$ diabaikan

h. Beban Temperatur Merata, $E_{u n}$ diabaikan

i. Beban Gempa, $\mathrm{E}_{\mathrm{Q}}$

Penentuan respon spektrum berdasarkan RSI 2833-201X

Berdasarkan lokasi, diperoleh parameter untuk respon spectra sebagai berikut:

Site class $\quad=\mathrm{S}_{\mathrm{E}}$ (Tanah Lunak)

0.2 second Acceleration response spectra $\quad=0.50 \mathrm{~g}$

1 second acceleration response spectra $=0.25 \mathrm{~g}$

PGA $\quad=0.25$

Percepatan Puncak di permukaan

Tanah (As) $\quad=0.30$

SDS $\quad=0.85 \mathrm{~g}$

SD1 $\quad=0.75 \mathrm{~g}$

Nilai modifikasi respons $\mathrm{R}$ yang dipakai:

Untuk perencanaan struktur pile cap, kolom dan balok pier digunakan $\mathrm{R}=2.0$ untuk gempa arah $\mathrm{X}$ dan $\mathrm{Y}$, sedangkan untuk perencanaan pondasi tiang pancang digunakan $\mathrm{R}=1.0$ untuk arah $\mathrm{X}$ maupun $\mathrm{Y}$

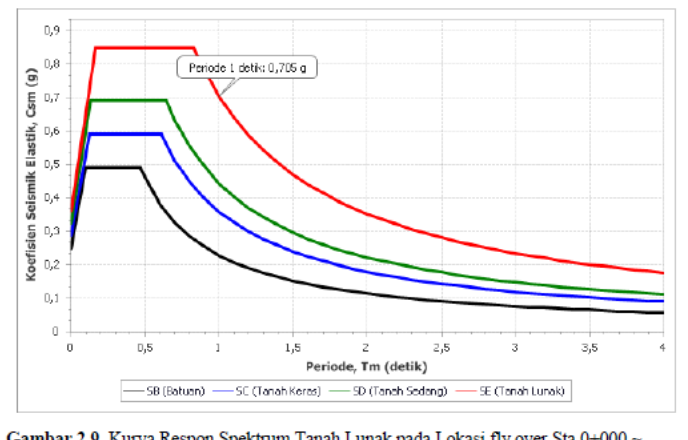

Gambar 2.9. Kurva Respon Spektrum Tanah Lunak pada Lokasi fly over Sta $0+000$ $+971$

Gambar 5. Kurva Respon Spektrum Tanah Lunak pada Lokasi Flyover Sta. 0+000 - 2+971

j. Kombinasi Pembebanan

Berdasarkan SNI 2847-2013, SNI 17252016, dan RSNI 2833-201X, perencanaan dan evaluasi struktur beton bertulang untuk jembatan kategori penting harus menggunakan kombinasi pembebanan sebagai berikut:

1. Kombinasi Pembebanan Normal
Kuat $1(\mathrm{D})=1.3 \mathrm{MS}+2.0 \mathrm{MA}+1.8$

$\mathrm{TD}+1.8 \mathrm{~TB}$

Kuat $1(\mathrm{~T})=1.3 \mathrm{MS}+2.0 \mathrm{MA}+1.8$

$\mathrm{TT}+1.8 \mathrm{~TB}$

Kuat $3=1.3 \mathrm{MS}+2.0 \mathrm{MA}+1.4 \mathrm{EWS}$

2. Kombinasi Pembebanan Akibat

Gempa

Extrem $1(\mathrm{R}=1)=1.3 \mathrm{MS}+2.0 \mathrm{MA}+$

$0.3 \mathrm{TD}+1.0 \mathrm{EQX}+0.3 \mathrm{EQY}$

Extrem $1(\mathrm{R}=1)=1.3 \mathrm{MS}+2.0 \mathrm{MA}+$

$0.3 \mathrm{TD}+0.3 \mathrm{EQX}+1.0 \mathrm{EQY}$

Extrem $1(\mathrm{R}=1)=1.3 \mathrm{MS}+2.0 \mathrm{MA}+$

$0.3 \mathrm{TT}+1.0 \mathrm{EQX}+0.3 \mathrm{EQY}$

Extrem $1(\mathrm{R}=1)=1.3 \mathrm{MS}+2.0 \mathrm{MA}+$

$0.3 \mathrm{TT}+0.3 \mathrm{EQX}+1.0 \mathrm{EQY}$

Extrem $1(\mathrm{R}=2)=1.3 \mathrm{MS}+2.0 \mathrm{MA}+$

$0.3 \mathrm{TD}+1.0 \mathrm{EQX}+0.3 \mathrm{EQY}$

Extrem $1(\mathrm{R}=2)=1.3 \mathrm{MS}+2.0 \mathrm{MA}+$

$0.3 \mathrm{TD}+0.3 \mathrm{EQX}+1.0 \mathrm{EQY}$

Extrem $1(\mathrm{R}=2)=1.3 \mathrm{MS}+2.0 \mathrm{MA}+$

$0.3 \mathrm{TT}+1.0 \mathrm{EQX}+0.3 \mathrm{EQY}$

Extrem $1(\mathrm{R}=2)=1.3 \mathrm{MS}+2.0 \mathrm{MA}+$

$0.3 \mathrm{TT}+0.3 \mathrm{EQX}+1.0 \mathrm{EQY}$

3. Kombinasi Pembebanan Service

Service $1=1.0 \mathrm{MS}+1.0 \mathrm{MA}+1.0 \mathrm{TD}$

$+1.0 \mathrm{~TB}+0.3 \mathrm{Ews}$

Service $1=1.0 \mathrm{MS}+1.0 \mathrm{MA}+1.0 \mathrm{TT}$ $+1.0 \mathrm{~TB}+0.3 \mathrm{Ews}$

Service $2=1.0 \mathrm{MS}+1.0 \mathrm{MA}+1.3 \mathrm{TD}$ $+1.3 \mathrm{~TB}$

Service $2=1.0 \mathrm{MS}+1.0 \mathrm{MA}+1.3 \mathrm{TT}$ $+1.3 \mathrm{~TB}$

\section{Analisa dan Pembahasan \\ Daya Dukung Pondasi Tiang Pancang}

Kapasitas material tiang pancang berdasarkan spesifikasi teknis kapasitas material ijin tiang pancang yang digunakan berdasarkan rencana kelas adalah sebagai berikut:

- Tiang pancang Sisi Atas - diameter 600 Kelas C

$\mathrm{P}_{\text {allowable }}=229.50$ ton

$\mathrm{M}_{\mathrm{ult}} \quad=58.00$ ton.meter

$\mathrm{M}_{\text {crack }}=29.00$ ton.meter

- Tiang Pancang Sisi Bawah - diameter 600 Kelas A1

$$
\begin{aligned}
& \mathrm{P}_{\text {allowable }}=252.70 \text { ton } \\
& \mathrm{M}_{\text {ult }}=17.00 \text { ton.meter } \\
& \mathrm{M}_{\text {crack }}=25.50 \text { ton.meter }
\end{aligned}
$$


Sedangkan kelas situs adalah sebagai berikut:

- Kelas situs Sta. $0+400=$ SD

- Kelas situs sta. $0+750=\mathrm{SE}$

- Kelas situs sta. $1+000=\mathrm{SE}$

- Kelas situs sta. $2+300=\mathrm{SE}$

\section{Desain Struktur Fly Over Sta. 0+400 Bentang 40 meter}

\section{Struktur Balok Pier Head}

Dari hasil analisa diperoleh dimensi balok sebagai berikut:

Lebar Balok $\quad \mathrm{b}=1800 \mathrm{~mm}$

Tinggi balok $\mathrm{h}=3450 \mathrm{~mm}$

Selimut beton d' $\quad=50 \mathrm{~mm}$

Tinggi efektif $\mathrm{d}=3400 \mathrm{~mm}$

Rekapitulasi Penulangan Balok Pier Head Sta. 0+400 adalah sebagai berikut:

\section{Tumpuan}

Tulangan tarik $\quad \mathrm{A}_{\mathrm{ST}}=32 \mathrm{D} 32$

Tulangan tekan $\quad \mathrm{A}_{\mathrm{Sc}}=19 \mathrm{D} 32$

Tulangan Badan $\quad \mathrm{A}_{\mathrm{sv}}=10 \mathrm{D} 32$

Tulangan geser $\quad=\quad \mathrm{D} 25-150$

Lapangan

Tulangan tarik $\quad \mathrm{A}_{\mathrm{ST}}=32 \mathrm{D} 32$

Tulangan tekan $\quad \mathrm{A}_{\mathrm{Sc}}=19 \mathrm{D} 32$

Tulangan Badan $\quad \mathrm{A}_{\mathrm{sv}}=11 \mathrm{D} 32$

Tulangan geser $=\mathrm{D} 25-200$

\section{Struktur PCI Girder}

Hasil perhitungan SAP menunjukkan reaksi (Vult) pada balok Girder sebesar $1516,086 \mathrm{kN}$. Untuk elastomer yang digunakan adalah tipe $\mathrm{B}$ dengan dimensi 300 x 400 x 57 dengan kapasitas $2071 \mathrm{kN}$. Sedangkan panjang perletakan minimum untuk tumpuan girder dan perletakan elastomer sebesar $1000 \mathrm{~mm}$.
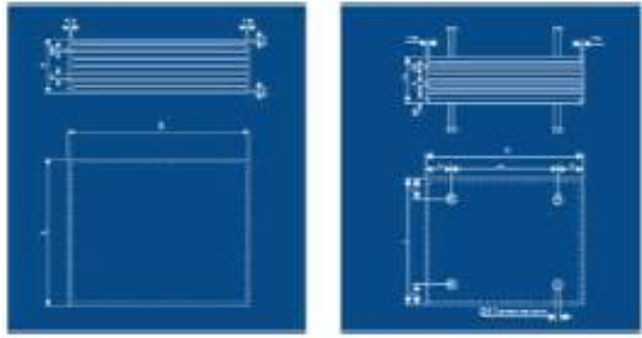

Gambar 6. Desain Elastomer
3. Konsol Pendek untuk Tumpuan Girder

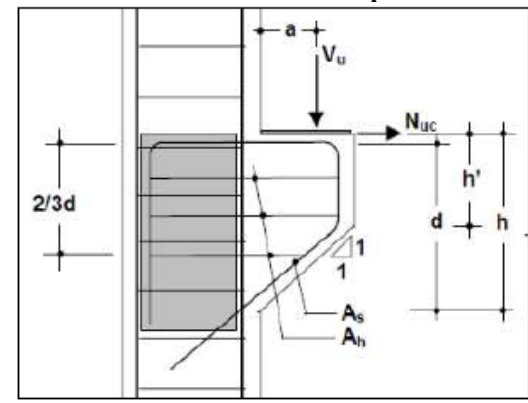

Gambar 7. Konsol Pendek

Dimensi untuk konsol pendek adalah:

Lebar, b

$=1000$

$\mathrm{mm}$

Tinggi total, $\mathrm{H}=2000 \quad \mathrm{~mm}$

Tinggi efektif, $\mathrm{d}=1925 \mathrm{~mm}$

Tulangan utama $=$ D32-125

Tul. horisontal $=$ D25-200

4. Kolom Pier

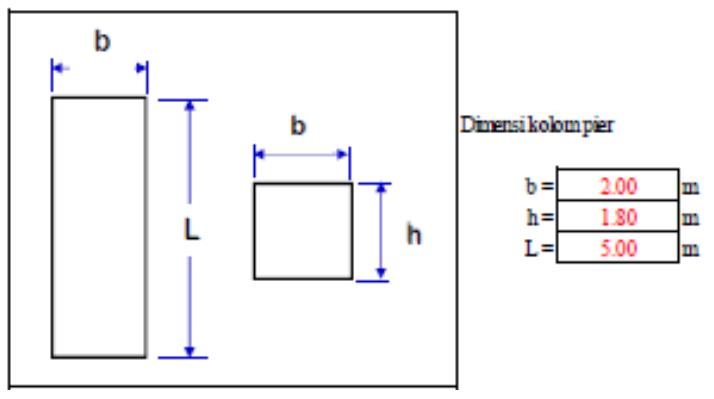

Gambar 8. Dimensi Kolom Pier Sta. 0+400

Penulangan kolom pier adalah sebagai berikut:

Tulangan longitudinal

Tulangan geser

$$
\begin{aligned}
& =\quad 92 \mathrm{D} 32 \\
& =\quad \mathrm{D} 16-150
\end{aligned}
$$

5. Pondasi

Rekapitulasi perencanaan penulangan pondasi adalah sebagai berikut:

Tiang Pancang

Kebutuhan untuk $1=35$ D 600

pilar

Kedalaman

$=13 \mathrm{~m}$

Tulangan utama

$=\quad 18 \mathrm{D} 22$

Tulangan Geser

$=\mathrm{D} 13-75$

Pile Cap

Arah-x

Tulangan lentur

$=\quad \mathrm{D} 32-200$

Tulangan susut

$=\mathrm{D} 25-200$

Tulangan geser

$=\mathrm{D} 25-200$

Arah-y

Tulangan lentur $=\mathrm{D} 32-150$

Tulangan susut $\quad=\quad \mathrm{D} 25-150$

Tulangan geser $\quad=\quad$ D $25-400$ 


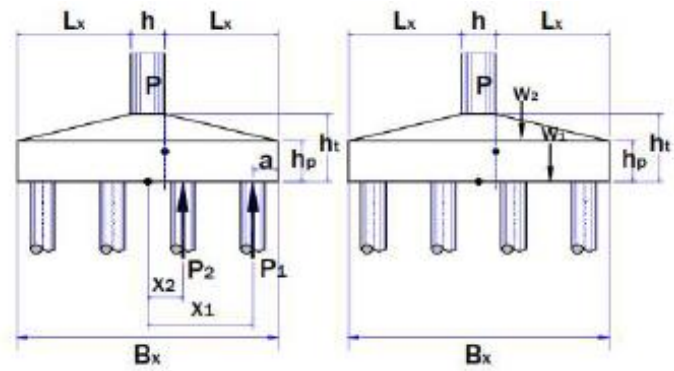

Gambar 9. Pile Cap Arah-x
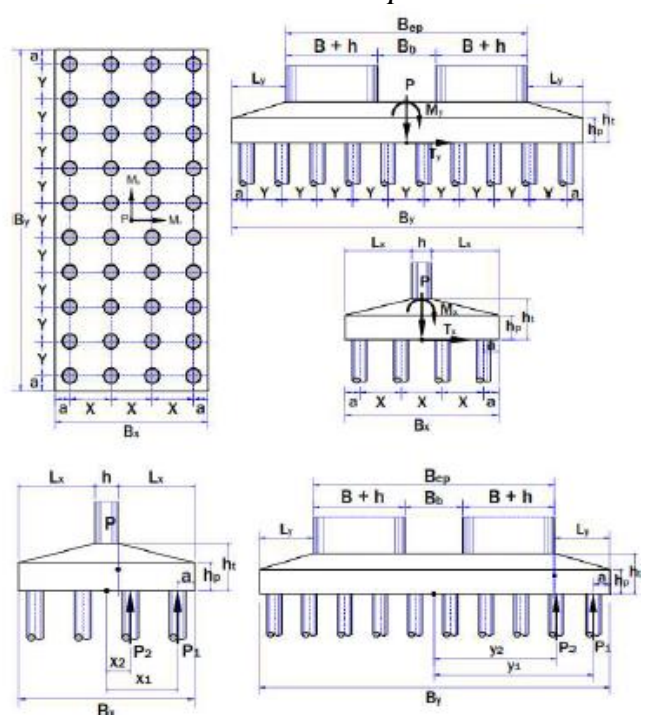

Gambar 10. Pile Cap Arah-y

\section{Desain Struktur Fly Over Sta $0+750$ Bentang 40 Meter}

1. Struktur Balok Pier Head

Dari hasil analisa diperoleh dimensi balok sebagai berikut:

Lebar Balok $\quad \mathrm{b}=2000 \mathrm{~mm}$

Tinggi balok $\mathrm{h}=3650 \mathrm{~mm}$

Selimut beton d' $\quad=60 \mathrm{~mm}$

Tinggi efektif $\mathrm{d}=3590 \mathrm{~mm}$

Rekapitulasi Penulangan Balok Pier Head Sta. $0+750$ adalah sebagai berikut:
Tumpuan
Tulangan tarik
$\mathrm{A}_{\mathrm{ST}}=37 \mathrm{D} 32$
Tulangan tekan
$\mathrm{A}_{\mathrm{Sc}}=22 \mathrm{D} 32$
Tulangan Badan
Tulangan geser
$\mathrm{A}_{\mathrm{SV}}=12 \mathrm{D} 32$
$=\mathrm{D} 25-150$
Lapangan
Tulangan tarik $\quad \mathrm{A}_{\mathrm{ST}}=39 \mathrm{D} 32$
Tulangan tekan $\quad \mathrm{A}_{\mathrm{Sc}}=23 \mathrm{D} 32$
Tulangan Badan $\mathrm{A}_{\mathrm{SV}}=15 \mathrm{D} 32$
Tulangan geser $\quad=\quad \mathrm{D} 25-200$

2. Struktur PCI Girder

Hasil perhitungan SAP menunjukkan reaksi (Vult) pada balok Girder sebesar 1567,56 kN. Desain elastomer seperti gambar
6. menggunakan tipe $\mathrm{B}$ dengan dimensi $300 \mathrm{x}$ 400 x 57 dan kapasitas 2071 kN. Sedangkan panjang perletakan minimum untuk tumpuan girder dan perletakan elastomer sebesar 1000 $\mathrm{mm}$.

3. Konsol Pendek untuk Tumpuan Girder

Desain konsol pendek seperti gambar 7., dengan dimensi sebagai berikut:

Lebar, b

$=1000$

Tinggi total, $\mathrm{H}=2200$

Tinggi efektif, $\mathrm{d}=2125$

Tulangan utama $=$ D32-150

Tul. horisontal $=$ D25-200

4. Kolom Pier

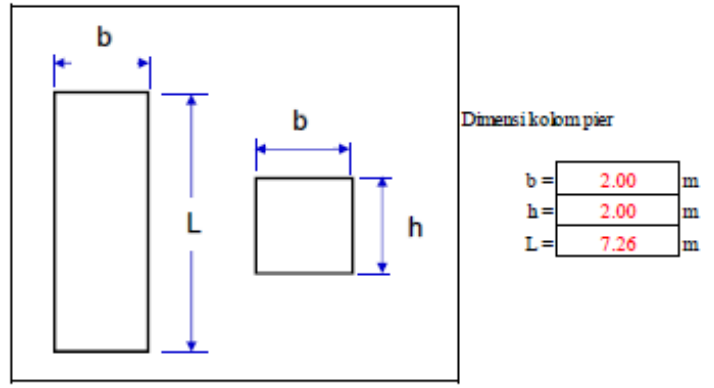

Gambar 11. Dimensi Kolom Pier Sta. 0+750

Penulangan kolom pier adalah sebagai berikut:
Tulangan longitudinal
$=100 \mathrm{D} 32$
Tulangan geser
$=\mathrm{D} 16-150$

5. Pondasi

Rekapitulasi perencanaan penulangan pondasi adalah sebagai berikut:

Tiang Pancang

Kebutuhan untuk 1 pilar $=50 \mathrm{D} 600$

Kedalaman $\quad=\quad 3 \mathrm{~m}$

Tulangan utama $\quad=18 \mathrm{D} 22$

Tulangan Geser $\quad=$ D13 -75

Pile Cap

Arah-x

Tulangan lentur $\quad=\quad \mathrm{D} 32-150$

Tulangan susut $\quad=$ D $25-200$

Tulangan geser $\quad=\quad \mathrm{D} 19-400$

Arah-y

Tulangan lentur $\quad=\quad \mathrm{D} 32-100$

Tulangan susut $\quad=\quad \mathrm{D} 25-150$

Tulangan geser $\quad=\quad \mathrm{D} 25-400$

Panjang penyaluran $\quad=1000 \mathrm{~mm}$

\section{Desain Struktur Fly Over Sta $2+300$}

\section{Bentang 20 dan 40 Meter}

1. Struktur Balok Pier Head

Dari hasil analisa diperoleh penulangan balok pier head dimensi 2000x1500 sebagai berikut: 
Tumpuan

Tulangan tarik

Tulangan tekan

Tulangan Badan

Tulangan geser

Lapangan

Tulangan tarik

Tulangan tekan

Tulangan Badan

Tulangan geser

$$
\begin{aligned}
\mathrm{A}_{\mathrm{ST}} & =31 \mathrm{D} 25 \\
\mathrm{~A}_{\mathrm{Sc}} & =18 \mathrm{D} 25 \\
\mathrm{~A}_{\mathrm{SV}} & =10 \mathrm{D} 25 \\
& =\mathrm{D} 22-150 \\
\mathrm{~A}_{\mathrm{ST}} & =25 \mathrm{D} 25 \\
\mathrm{~A}_{\mathrm{Sc}} & =15 \mathrm{D} 25 \\
\mathrm{~A}_{\mathrm{SV}} & =9 \mathrm{D} 25 \\
& =\mathrm{D} 22-200
\end{aligned}
$$

Dari hasil analisa diperoleh penulangan balok pier head dimensi 2000x3500 sebagai berikut:

$$
\begin{array}{llll}
\text { Tumpuan } & & \\
\text { Tulangan tarik } & \mathrm{A}_{\mathrm{ST}} & =36 \mathrm{D} 32 \\
\text { Tulangan tekan } & \mathrm{A}_{\mathrm{Sc}} & =21 \mathrm{D} 32 \\
\text { Tulangan Badan } & \mathrm{A}_{\mathrm{SV}} & =12 \mathrm{D} 32 \\
\text { Tulangan geser } & & = & \mathrm{D} 25-150 \\
\text { Lapangan } & & & \\
\text { Tulangan tarik } & \mathrm{A}_{\mathrm{ST}} & =37 \mathrm{D} 32 \\
\text { Tulangan tekan } & \mathrm{A}_{\mathrm{Sc}} & =22 \mathrm{D} 32 \\
\text { Tulangan Badan } & \mathrm{A}_{\mathrm{SV}} & =14 \mathrm{D} 32 \\
\text { Tulangan geser } & & = & \mathrm{D} 25-200
\end{array}
$$

\section{Struktur PCI Girder}

Hasil perhitungan SAP menunjukkan reaksi (Vult) pada balok Girder sebesar $1553,975 \mathrm{kN}$. Desain elastomer seperti gambar 6. menggunakan tipe $\mathrm{B}$ dengan dimensi 250 x 300 x 41 dan kapasitas 2071 $\mathrm{kN}$. Sedangkan panjang perletakan minimum untuk tumpuan girder dan perletakan elastomer sebesar $800 \mathrm{~mm}$ dan $1000 \mathrm{~mm}$.

\section{Konsol Pendek}

Desain konsol pendek untuk bentang $40 \mathrm{~m}$ seperti gambar 7., dengan dimensi sebagai berikut:

$\begin{array}{llll}\text { Lebar, b } & =1000 & \mathrm{~mm} \\ \text { Tinggi total, } \mathrm{H} & =2000 & \mathrm{~mm} \\ \text { Tinggi efektif, d } & =1925 & \mathrm{~mm} \\ \text { Tulangan utama } & = & \text { D32-150 } & \\ \text { Tul. horisontal } & = & \text { D25-250 } & \end{array}$

Desain konsol pendek untuk bentang 20 adalah sebagai berikut:

$\begin{array}{llll}\text { Lebar, } \mathrm{b} & = & 1000 & \mathrm{~mm} \\ \text { Tinggi total, } \mathrm{H} & = & 1800 & \mathrm{~mm} \\ \text { Tinggi efektif, d } & = & 1725 & \mathrm{~mm} \\ \text { Tulangan utama } & = & \mathrm{D} 25-150 & \\ \text { Tul. horisontal } & = & \mathrm{D} 25-500 & \end{array}$

\section{Kolom Pier}

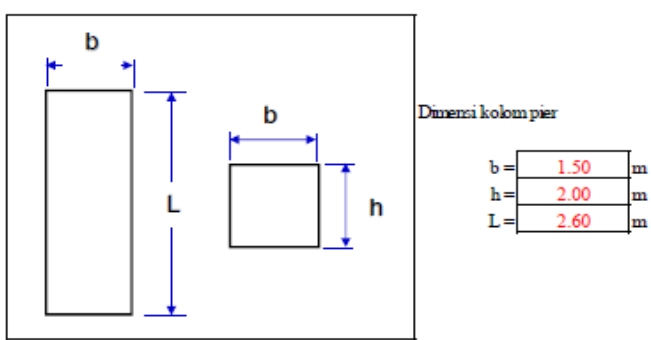

Gambar 12. Dimensi Kolom Pier Sta. 2+30 (1500 $\mathrm{x}$ 2000)

Penulangan kolom pier adalah sebagai berikut:

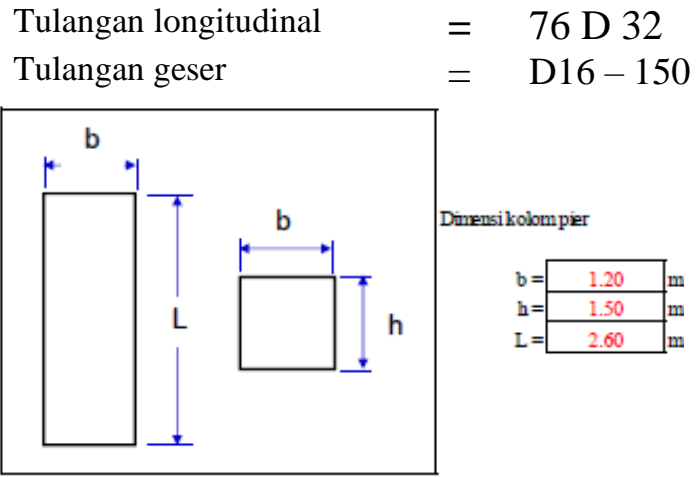

Gambar 13. Dimensi Kolom Pier Sta. 2+30 (1500 $\mathrm{x}$ 1200)

Penulangan kolom pier adalah sebagai berikut:

$$
\begin{array}{lll}
\text { Tulangan longitudinal } & = & 48 \mathrm{D} 32 \\
\text { Tulangan geser } & = & \mathrm{D} 16-150
\end{array}
$$

5. Pondasi

Rekapitulasi perencanaan penulangan pondasi adalah sebagai berikut:

Tiang Pancang bentang $40 \mathrm{~m}$

Kebutuhan untuk 1 pilar $=40$ D 600

Kedalaman $\quad=3 \mathrm{~m}$

Tulangan utama $\quad=18 \mathrm{D} 22$

Tulangan Geser $\quad=$ D13-75

Tiang Pancang bentang $20 \mathrm{~m}$

Kebutuhan untuk 1 pilar $=27$ D 600

Kedalaman $\quad=3 \mathrm{~m}$

Tulangan utama $\quad=18 \mathrm{D} 22$

Tulangan Geser $\quad=$ D13-75

Pile Cap Bentang $40 \mathrm{~m}$

Arah-x

Tulangan lentur $\quad=\quad \mathrm{D} 25-150$

Tulangan susut $\quad=$ D 25-300

Tulangan geser $\quad=\quad$ D $19-400$

Arah-y

Tulangan lentur $\quad=\quad$ D 32-150

Tulangan susut $\quad=$ D 25-150

Tulangan geser $\quad=$ D $19-400$

Panjang penyaluran $\quad=1000 \mathrm{~mm}$ 
Pile Cap Bentang $20 \mathrm{~m}$

Arah-X

Tulangan lentur

$=\mathrm{D} 25-150$

Tulangan susut

$=\mathrm{D} 25-150$

Tulangan geser

$=\mathrm{D} 25-150$

Arah-y

Tulangan lentur

$=\mathrm{D} 25-150$

Tulangan susut

$=\mathrm{D} 25-150$

Tulangan geser

Panjang penyaluran
$=\mathrm{D} 25-400$

$=1000 \mathrm{~mm}$

\section{Desain Struktur Fly Over Sta 0+750}

Bentang 30 Meter

\section{Struktur Balok Pier Head}

Dari hasil analisa diperoleh dimensi balok sebagai berikut:

$\begin{array}{lllll}\text { Lebar Balok } & \mathrm{b} & = & 2000 \mathrm{~mm} \\ \text { Tinggi balok } & \mathrm{h} & = & 3500 \mathrm{~mm} \\ \text { Selimut beton } & \mathrm{d} & = & 50 \mathrm{~mm} \\ \text { Tinggi efektif } & \mathrm{d} & = & 3450 \mathrm{~mm}\end{array}$

Rekapitulasi Penulangan Balok Pier Head Sta.

0+750 bentang $30 \mathrm{~m}$ adalah sebagai berikut:

Tumpuan

Tulangan tarik $\quad \mathrm{A}_{\mathrm{ST}}=38 \mathrm{D} 32$

Tulangan tekan $\quad \mathrm{A}_{\mathrm{Sc}}=23 \mathrm{D} 32$

Tulangan Badan $\mathrm{A}_{\mathrm{SV}}=16 \mathrm{D} 32$

Tulangan geser $\quad=\quad \mathrm{D} 19-150$

Lapangan

Tulangan tarik $\quad \mathrm{A}_{\mathrm{ST}}=38 \mathrm{D} 32$

Tulangan tekan $\mathrm{A}_{\mathrm{Sc}}=23 \mathrm{D} 32$

Tulangan Badan $\mathrm{A}_{\mathrm{SV}}=16 \mathrm{D} 32$

Tulangan geser $\quad=\quad \mathrm{D} 19-150$

2. Struktur PCI Girder

Hasil perhitungan SAP menunjukkan reaksi (Vult) pada balok Girder sebesar $1155,1 \mathrm{kN}$. Desain elastomer seperti gambar 6. menggunakan tipe $\mathrm{B}$ dengan dimensi $300 \mathrm{x}$ 400 x 57 dan kapasitas 2071 kN. Sedangkan panjang perletakan minimum untuk tumpuan girder dan perletakan elastomer sebesar 800 $\mathrm{mm}$.

3. Konsol Pendek untuk Tumpuan Girder

Desain konsol pendek seperti gambar 7 ., dengan dimensi sebagai berikut:

$\begin{array}{llll}\text { Lebar, } \mathrm{b} & = & 1000 & \mathrm{~mm} \\ \text { Tinggi total, } \mathrm{H} & = & 1250 & \mathrm{~mm} \\ \text { Tinggi efektif, d } & = & 1175 & \mathrm{~mm} \\ \text { Tulangan utama } & = & \text { D25-150 } & \\ \text { Tul. horisontal } & = & \text { D19-150 } & \end{array}$

4. Kolom Pier

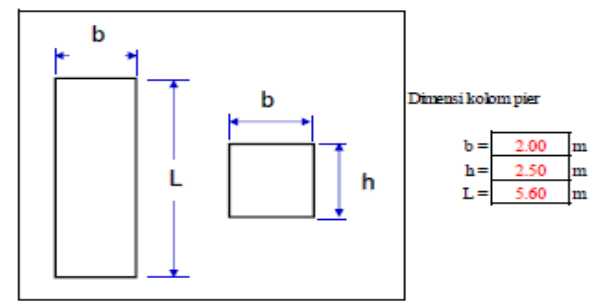

Gambar 14. Dimensi Kolom Pier Sta. 0+750 bentang 30 meter

Penulangan kolom pier adalah sebagai berikut:

Tulangan longitudinal $=125 \mathrm{D} 32$

Tulangan geser $\quad=\quad \mathrm{D} 16-150$

5. Pondasi

Rekapitulasi perencanaan penulangan pondasi adalah sebagai berikut:

Tiang Pancang

Kebutuhan untuk $1=24$ D 600

pilar

Kedalaman $\quad=3 \mathrm{~m}$

Tulangan utama $\quad=18 \mathrm{D} 22$

Tulangan Geser $\quad=$ D13-75

Pile Cap

Arah-x

Tulangan lentur $=\mathrm{D} 32-200$

Tulangan susut $\quad=\mathrm{D} 25-200$

Tulangan geser $\quad=\mathrm{D} 16-450$

Arah-y

Tulangan lentur $=\mathrm{D} 32-150$

Tulangan susut $\quad=\quad \mathrm{D} 25-150$

Tulangan geser $\quad=\quad \mathrm{D} 16-500$

Panjang penyaluran $\quad=1000 \mathrm{~mm}$

\section{Desain Struktur Full Slab/ Pelat Precast}

\section{Dimensi Pelat}

Dimensi struktur pelat precast adalah sebagai berikut:

$\begin{array}{llll}\text { Panjang } & \mathrm{L} & =5.00 \mathrm{~m} \\ \text { Lebar } & \mathrm{b} & = & 2.25 \mathrm{~m} \\ \text { Panjang bersih } & \mathrm{ln}= & 5.00 \mathrm{~m} \\ \text { Tebal } & \mathrm{t}_{\mathrm{p}}= & 40.00 \mathrm{~cm}\end{array}$

2. Pembebanan

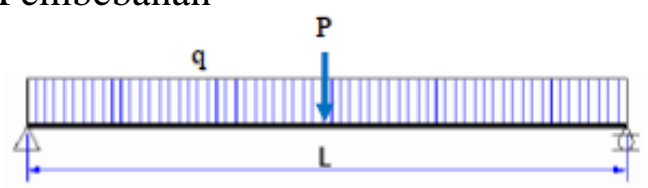

Gambar 15. Beban Kombinasi Pelat Kombinasi pembebanan yang digunakan adalah:

1. Kombinasi Kuat $1=1.2 \mathrm{Q}_{\mathrm{MS} . \mathrm{S}}+2$ $\mathrm{Q}_{\mathrm{MAS}}+1.8 \mathrm{P}_{\mathrm{KEL}}+1.8 \mathrm{QD}_{\mathrm{D}}$ 
2. Kombinasi Kuat $2=1.2$ QMS.S +2 $\mathrm{Q}_{\mathrm{MAS}}+1.8 \mathrm{P}_{\mathrm{TT}}$

Dari hasil perhitungan diperoleh:

$\begin{array}{llll}\mathrm{M}_{\text {komb.1 }} & \mathrm{Mu}_{1}=58719.38 & \mathrm{~kg} . \mathrm{m} \\ \mathrm{V}_{\text {komb1 }} & \mathrm{Vu}_{1} & =46975.50 & \mathrm{~kg} \\ \mathrm{M}_{\text {komb.2 }} & \mathrm{Mu} .2 & =83475.00 & \mathrm{~kg} . \mathrm{m} \\ \mathrm{V}_{\text {komb.2 }} & \mathrm{Vu} .2 & =66780.00 \mathrm{~kg}\end{array}$

3. Penulangan saat kondisi pengangkatan Penulangan plat arah- $x$ akibat pengangkatan menggunakan tulangan D13-150

Penulangan plat arah-y akibat pengangkatan menggunakan tulangan D13-150

Gambar 16. Penulangan Plat Arah-y Akibat Pengangkatan

Kontrol kapasitas penampang menunjukan bahwa tahanan momen plat lebih besar daripada $\mathbf{M}_{\text {ult. }}$ Kontrol persyaratan penulangan plat pracetak terhadap geser dan retak, serta kontrol tegangan akibat pengangkatan terpenuhi.

Tulangan untuk angkur menggunakan tulangan diameter $13 \mathrm{~mm}$, berdasarkan perhitungan maka lendutan yang terjadi sebesar 0,43325 $\mathrm{mm}$ dimana nilai ini lebih kecil daripada lendutan ijin yaitu sebesar $20.833 \mathrm{~mm}$.

4. Penulangan Saat Kondisi Beban Ultimit Tumpuan Sederhana

Penulangan setelah komposit arah- $\mathrm{x}$ menggunakan tulangan utama D13 - 150 $\mathrm{mm}$. Sedangkan penulangan setelah komposit arah-y menggunakan tulangan utama D22 - $100 \mathrm{~mm}$. Kontrol kapasitas penampang menunjukkan tahanan nominal pelat lebih besar dari $\mathrm{Mu}$, sehingga penampang aman.

Tulangan susut menggunakan tulangan D19 - $200 \mathrm{~mm}$ dan tulangan geser menggunakan tulangan D13 - $150 \mathrm{~mm}$.

Kontrol terhadap retak dan lendutan menunjukkan penampang masih memenuhi batas ijin

5. Penulangan Kondisi Saat Beban Ultimit Tumpuan Monolit
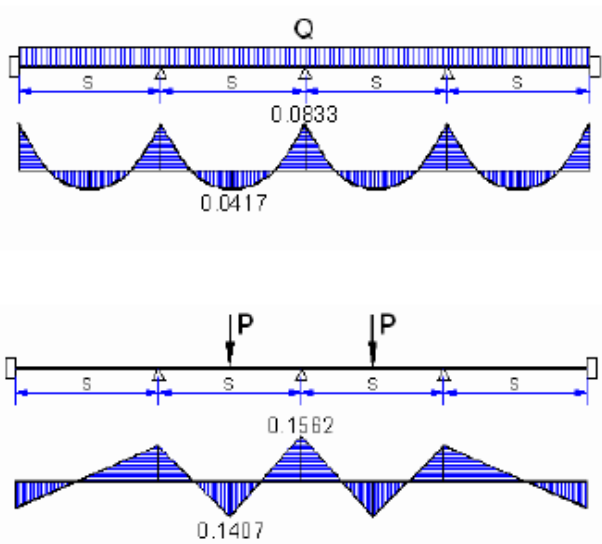

Gambar 17. Konfigurasi Pembebanan dengan Tumpuan Monolit ( $\mathrm{s}=6$ meter)

Dari hasil analisa diperoleh tulangan utama pelat arah-y D 22 - 100, tulangan susut D19-200, dan tulangan geser D13 150.

\section{Desain Struktur Slab On Pile Sta. 0+250 -}

\section{Sta. 0+300}

1. Penentuan Elastomer

Berdasarkan hasil perhitungan SAP, gaya geser yang berkerja pada full slab sebesar $289,78 \mathrm{kN}$. Pbearing sebesar 514,78 kN. Maka digunakan elastomer sebagai berikut:

$\begin{array}{ll}\text { Tipe } & =\mathrm{B} \\ \text { Dimensi } & =150 \times 300 \times 41 \\ \text { Kapasitas } & =607 \mathrm{kN}\end{array}$

2. Penentuan Tiang Pancang

Kebutuhan tiang pancang hasil perhitungan beban adalah:

Kebutuhan 1 pilar $\quad=\quad 10$ D 600

Kedalaman $\quad=3 \mathrm{~m}$

Tulangan utama $\quad=18 \mathrm{D} 22$

Tulangan Geser $\quad=$ D13-75

Panjang penyaluran $=1000$

3. Penulangan Balok Pile Head

Dari hasil analisa diperoleh dimensi balok sebagai berikut:

Lebar Balok $\quad \mathrm{b}=2000 \mathrm{~mm}$

Tinggi balok $\mathrm{h}=3500 \mathrm{~mm}$

Selimut beton d' $=50 \mathrm{~mm}$

Tinggi efektif $\mathrm{d}=3450 \mathrm{~mm}$

Rekapitulasi Penulangan Balok Pier Head Sta.

$0+250$ - Sta. $0+300$ (PH.1400.600 dan

PH.1100.600) adalah sebagai berikut:

Tumpuan

Tulangan tarik $\quad \mathrm{A}_{\mathrm{ST}}=38 \mathrm{D} 32$

Tulangan tekan $\mathrm{A}_{\mathrm{Sc}}=23 \mathrm{D} 32$ 


$\begin{array}{lll}\begin{array}{l}\text { Tulangan } \\ \text { Badan }\end{array} & \mathrm{A}_{\mathrm{SV}} & =16 \mathrm{D} 32 \\ \begin{array}{l}\text { Tulangan geser } \\ \text { Lapangan }\end{array} & & =\mathrm{D} 19-150 \\ \begin{array}{l}\text { Tulangan tarik } \\ \text { Tulangan tekan }\end{array} & \mathrm{A}_{\mathrm{ST}} & =38 \mathrm{D} 32 \\ \begin{array}{l}\text { Tulangan } \\ \text { Badan }\end{array} & \mathrm{A}_{\mathrm{SV}} & =16 \mathrm{D} 32 \\ \text { Tulangan geser } & & =\mathrm{D} 19-150\end{array}$

\section{Desain Struktur Slab On Pile Sta 1+000 -} Sta $2+250$

1. Penentuan Elastomer

Berdasarkan hasil perhitungan SAP, gaya geser yang berkerja pada full slab sebesar 339,85 kN. Pbearing sebesar 564,85 kN. Maka digunakan elastomer sebagai berikut:

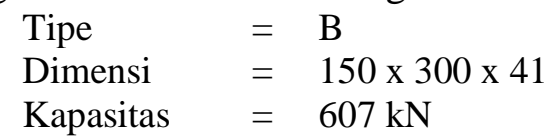

2. Penentuan Tiang Pancang

Kebutuhan tiang pancang hasil perhitungan beban adalah:

$\begin{array}{ll}\text { Kebutuhan 1 pilar } & =10 \mathrm{D} 600 \\ \text { Kedalaman } & =27 \mathrm{~m} \\ \text { Tulangan utama } & =18 \mathrm{D} 22 \\ \text { Tulangan Geser } & =\mathrm{D} 13-75 \\ \text { Panjang penyaluran } & =1000\end{array}$

3. Penulangan Balok Pile Head

Dari hasil analisa diperoleh dimensi balok sebagai berikut:

Lebar Balok $\quad \mathrm{b} \quad=1400 \mathrm{~mm}$

Tinggi balok $\mathrm{h}=600 \mathrm{~mm}$

Selimut beton d' $\quad=50 \mathrm{~mm}$

Tinggi efektif $\mathrm{d}=550 \mathrm{~mm}$

Rekapitulasi penulangan balok Pier Head Sta. $1+000$ - Sta. $2+250$ (PH.1400.600) adalah sebagai berikut:

Tumpuan

Tulangan tarik

Tulangan tekan

Tulangan Badan

Tulangan geser

Lapangan

Tulangan tarik

Tulangan tekan

Tulangan Badan

Tulangan geser

$$
\begin{aligned}
\mathrm{A}_{\mathrm{ST}} & =11 \mathrm{D} 22 \\
\mathrm{~A}_{\mathrm{Sc}} & =6 \mathrm{D} 22 \\
\mathrm{~A}_{\mathrm{SV}} & =4 \mathrm{D} 22 \\
& =\mathrm{D} 16-150
\end{aligned}
$$

$\mathrm{A}_{\mathrm{ST}}=11 \mathrm{D} 22$

$\mathrm{A}_{\mathrm{Sc}}=6 \mathrm{D} 22$

$\mathrm{A}_{\mathrm{SV}}=4 \mathrm{D} 22$

$=\mathrm{D} 16-150$

Sedangkan penulangan balok Pier Head Sta. $1+000$ - Sta. 2+250 (PH.600.1100) adalah sebagai berikut:

\section{Tumpuan}

$\begin{array}{lll}\text { Tulangan tarik } & \mathrm{A}_{\mathrm{ST}} & =9 \mathrm{D} 22 \\ \text { Tulangan tekan } & \mathrm{A}_{\mathrm{Sc}} & =5 \mathrm{D} 22 \\ \text { Tulangan Badan } & \mathrm{A}_{\mathrm{SV}} & =4 \mathrm{D} 22 \\ & =\mathrm{D} 16-150 \\ \text { Tulangan geser } & & \\ \text { Lapangan } & & \\ \text { Tulangan tarik } & \mathrm{A}_{\mathrm{ST}} & =9 \mathrm{D} 22 \\ \text { Tulangan tekan } & \mathrm{A}_{\mathrm{Sc}} & =5 \mathrm{D} 22 \\ \text { Tulangan Badan } & \mathrm{A}_{\mathrm{SV}} & =4 \mathrm{D} 22 \\ \text { Tulangan geser } & & =\mathrm{D} 16-200\end{array}$

\section{Desain Struktur Slab On Pile Sta 0+950}

1. Penentuan Elastomer

Berdasarkan hasil perhitungan SAP, gaya geser yang berkerja pada full slab adalah sebesar 289,78 kN. P bearing sebesar 514,78 $\mathrm{kN}$. Maka digunakan elastomer sebagai berikut:

$$
\begin{array}{ll}
\text { Tipe } & =\mathrm{B} \\
\text { Dimensi } & =150 \times 100 \times 41 \\
\text { kapasitas } & =607 \mathrm{kN}
\end{array}
$$

2. Penentuan Tiang Pancang

Kebutuhan tiang pancang hasil perhitungan beban adalah:

$$
\begin{array}{ll}
\text { Kebutuhan 1 pilar } & =10 \mathrm{D} 600 \\
\text { Kedalaman } & =3 \mathrm{~m} \\
\text { Tulangan utama } & =18 \mathrm{D} 22 \\
\text { Tulangan Geser } & =\mathrm{D} 13-75 \\
\text { Panjang penyaluran } & =1000
\end{array}
$$

3. Penulangan Balok Pile Head

Dari hasil analisa diperoleh dimensi balok sebagai berikut:

Lebar Balok $\quad b \quad=1400 \mathrm{~mm}$

Tinggi balok $\mathrm{h}=600 \mathrm{~mm}$

Selimut beton d' $=50 \mathrm{~mm}$

Tinggi efektif $\mathrm{d}=550 \mathrm{~mm}$

Rekapitulasi penulangan balok Pier Head Sta. 0+950 (PH.1400.600) adalah sebagai berikut:

\section{Tumpuan}

Tulangan tarik $\quad \mathrm{A}_{\mathrm{ST}}=13 \mathrm{D} 22$

Tulangan tekan $\quad \mathrm{A}_{\mathrm{Sc}}=7 \mathrm{D} 22$

Tulangan Badan $\quad \mathrm{A}_{\mathrm{SV}}=4 \mathrm{D} 22$

Tulangan geser $\quad=\mathrm{D} 16-150$

Lapangan

Tulangan tarik $\quad \mathrm{A}_{\mathrm{ST}}=13 \mathrm{D} 22$

Tulangan tekan $\quad \mathrm{A}_{\mathrm{Sc}}=7 \mathrm{D} 22$

Tulangan Badan $\mathrm{A}_{\mathrm{sv}}=4 \mathrm{D} 22$

Tulangan geser $\quad=$ D16-200

Sedangkan penulangan balok Pier Head Sta. 0+950 (PH.1100.600) adalah sebagai berikut:

Tumpuan

Tulangan tarik $\quad \mathrm{A}_{\mathrm{ST}}=11 \mathrm{D} 22$

Tulangan tekan $\quad \mathrm{A}_{\mathrm{Sc}}=6 \mathrm{D} 22$ 
Tulangan Badan

Tulangan geser

Lapangan

Tulangan tarik

Tulangan tekan

Tulangan Badan

Tulangan geser

\section{Desain Pelat Lantai Fly Over}

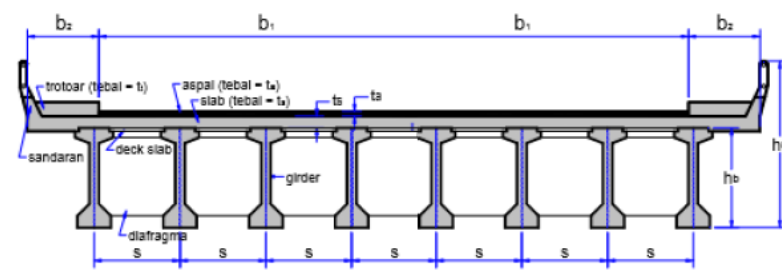

Gambar 18. Potongan Melintang Pelat Lantai Jembatan

Berdasarkan hasil perhitungan SAP dan Analisa, direncanakan tebal pelat (h) sebesar 250 $\mathrm{mm}$ dengan selimut beton (d') sebesar $40 \mathrm{~mm}$ dengan penulangan pelat jembatan sebagai berikut:

Tul. Lentur Tump. $\quad=\quad \mathrm{D} 19-100$

Tul. Susut Lentur Tump. $=$ D 19-200

Tul. Lentur Lap. $\quad=$ D $19-100$

Tul. Susut Lentur Lap. $\quad=\quad$ D 19-200

Hasil perhitungan lendutan pada pelat sebesar 2,152 mm. nilai ini lebih kecil dari lendutan ijin pelat sebesar 2,3125. Tegangan geser pons juga memenuhi batas tegangan gese ijin, sehingga desain pelat memenuhi faktor keamanan.

\section{Kesimpulan}

Dari hasil analisa dapat disimpulkan bahwa:

1. Desain fly over meliputi desain balok pier head, dengan dimensi bervariasi sesuai sta. yang direncanakan, dengan tulangan utama D32 dan tulangan geser D25. Elastomer yang digunakan tipe $\mathrm{B}$ dengan dimensi sesuai kebutuhan. Tulangan utama kolom pier D32, tulangan geser D16. Untuk tulangan utama tiang pancang D600 dengan tulangan utama D22 dan tulangan geser D13, sedangkan untuk pile, tulangan utama D32, tulangan geser D25. Jumlah tulangan sesuai hasil perhitungan dan analisa.
2. Desain pelat jembatan terdiri dari full slab dengan lebar $2,25 \mathrm{~m}$ dan panjang $5 \mathrm{~m}$. Untuk kondisi pengangkatan dan beban ultimit menggunakan tulangan utama D13. Sedangkan saat struktur komposit dan ultimit tumpuan monolit digunakan tulangan utama D22. Untuk desain slab on pile, menggunakan elastomer tipe $\mathrm{B}$ dimensi 150x300x41. Tiang pancang tipe C (D 600), tulangan utama D22, dan tulangan geser D13. Penulangan pile head menggunakan D32 dan D22 sedangkan tulangan geser D19 dan D16. Desain pelat lantai fly over menggunakan tulangan utama D19.

\section{Daftar Pustaka}

Badan Standardisasi Nasional. 2013. SNI 2847:2013. Persyaratan Beton Struktural untuk Bangunan Gedung. Jakarta.

Badan Standardisasi Nasional. 2016. SNI 1752:2016. Pembebanan untuk Jembatan. Jakarta.

Badan Standardisasi Nasional. RSNI2 2933201X. Perencanaan Ketahanan Gempa untuk Jembatan. Jakarta.

Das, Braja M. 1995. Mekanika Tanah (Prinsip-Prinsip Rekayasa Geoteknis) Jilid 1.Erlangga, Jakarta.

Pusat Penelitian dan Pengembangan Jalan dan Jembatan (PUSJATAN). 2017. Peta Sumber dan Bahaya Gempa Indonesia tahun 2017 untuk Jembatan. http://petagempa.pusjatan.pu.go.id/. 
